\title{
テラヘルツ帯電磁波を活用した医薬品・有機膜の 非破壊非接触品質分析
}

\author{
鈴木 大地 ${ }^{1,2}$, 河野 行雄 ${ }^{* 1}$
}

\begin{abstract}
医薬品や工業用材料等の製造業界において製品の安全性・信頼性への要求は年々増加しており，そのため に高い品質を保証する検查手法の開発・導入が重要課題の一つとして認識されている. そこで本研究では, 工程内検査に扔ける新規の非破壊・非接触分析手法としてテラヘルッ帯 $\left(\mathrm{THz}, 10^{12} \mathrm{~Hz}\right)$ 電磁波による分析 手法を活用し, 医薬品・有機膜等の品質分析を行った. THz 带電磁波特有の有機物に対する適度な透過性や 指紋スペクトルを利用することで, 可視光での画像解析や赤外分光といった既存の分析手法では難しい, パッケージ内の医薬品の分子同定や有機膜の膜厚評価, 多層有機膜内部におけるサブミリスケールの久損や 髪の毛・化学薬品混入の検查といった品質分析を実証した．本技術は医薬品・有機膜をはじめとする様々な 製品における高い品質を保証する分析技術であるといえ，製造業界における新規な検査手法としての実用化 が期待される.
\end{abstract}

\section{1 緒言}

近年，医薬品や航空機・自動車用部品といった高い安全 性を求められる業界において, 品質を取り巻く環境は変化 してきており，製品の高い品質を保証するために従来の最 終検查だけでなく，工程内検査の必要性が一段と増してき ている ${ }^{1)}$ ここのことは我が国だけでなく，日米欧医薬品規 制調和国際会議で合意された ICH-Q10（品質システム）ガ イドラインや, 国際標準化機構で策定された ISO 9000 シ リーズ（品質マネジメントシステム）においても，工程内 検査は製品品質を保証するための要素の一つであると定義 されており，国際的な立場での対応が盛んに進められてい $ろ^{2) 3)}$.

製造品の品質劣化を引き起こすリスク因子には，材料の 変形及び破損，金属片や髪の毛といった製造過程における 異物の混入, 偽造原料・原薬等の混入, 有害微生物の繁殖 など，多岐に渡る要因が存在するため，リスク因子にあわ せた適切な検查手法を導入する必要がある。このような ニーズに応えるため, 工程内検查に適する様々な検查技術 が開発されており, 可視光での画像処理による破損検查技 術 $^{45)}$, 近赤外分光法による造粒工程の膜質評価技術 ${ }^{6(8)}$, $X$ 線透過測定による内部検查等 ${ }^{910)}$ が幅広い領域にて実用 化され，製品の信頼性向上に不可欠な技術となっている.

\footnotetext{
*E-mail : kawano@ee.e.titech.ac.jp

${ }^{1}$ 東京工業大学科学技術創成研究院未来産業技術研究所工学院電 気電子系：152-8552 東京都目黒区大岡山 2-12-1

${ }^{2}$ 日本学術振興会 : 102-0083 東京都千代田区鿺町 5-3-1
}

以上のように，製造過程における工程内非破壊分析技術な らびに品質評価技術の開発・導入が，製造業界におけるメ イントピックの一つとして挙げられている.

このような背景を受け，著者らはテラヘルッ $(\mathrm{THz})$ 帯 電磁波を活用した非破壊検查手法の確立に取り組んでい る. THz 波はマイクロ波のように物質に対する高い透過率 を持ち，かつ赤外光のように物質固有の吸収スペクトルを 観測できるといった特徵を有する。 そのため, $\mathrm{THz}$ 帯電磁 波を用いたイメージングは，製品の内部に渡る空間情報及 び材質情報を得ることが可能な強力な分析手法として注目 を集めて抢り，THzイメージングの実用化に向け光源・検 出器の開発 ${ }^{11)}$ 13) やイメージング応用の研究例 ${ }^{14)}$ 16) が報告 されている。

本研究では，製造業界に扔ける非破壊・非接触分析手法 としての THzイメージング技術の導入を目的とし, THz带 電磁波を活用した医薬品や有機膜等における久損・混入物 検查等の品質分析を実施した. THz 带電磁波特有の有機物 に対する適度な透過性や指紋スペクトルを利用すること で, 超音波や可視光による画像解析等, 他の分析手法では 難しい, パッヶージ内医薬品の物質同定や有機膜の膜厚評 価，多層有機膜内部におけるサブミリスケールの欠損や髮 の毛・化学薬品混入の検査といった品質分析を達成した. 本技術は医薬品をはじめとする様々な業界における工程内 検查の強力な分析手法として実用化が期待できることか ら, 今回これらの成果について報告する. 


\section{2 分析手法}

本研究では, 医薬品・有機膜の分析手法としてテラヘル ツ時間領域分光法（Terahertz Time-Domain Spectroscopy: THz-TDS）を用いた. THz パルス波をサンプルに入射させ たのち, サンプルからの透過 $\mathrm{THz}$ 光を時間分解計測し, そ の時間波形をフーリエ変換することによって THz 帯の吸 光スペクトル特性を算出する. 周波数帯域 $0.5 \sim 7 \mathrm{THz}$ の パルス光源を使用して, 周波数分解能 $3.8 \mathrm{GHz}$ でスペクト ル測定を行った. また, 1 画素あたり 256 回の平均化処理 （1画素あたりの処理時間が約 4 秒）を行うことで $\mathrm{S} / \mathrm{N}$ 比 を向上させている.イメージングでは, 測定対象を二軸に 移動させ, 各地点で得られた吸光特性を統合することで, 測定対象の 2 次元 $\mathrm{THz}$ 吸収像を計測した（最大で 1 万画 素).

\section{3 医薬品分析}

$\mathrm{THz}$ 帯を用いた分光測定の特徴として, 大きな質量を持 つ高分子同士の分子間振動や分子の回転緩和といったサブ ピコ〜ピコ秒の周期を持つ運動のダイナミクスが分析で きることが挙げられる. 本研究では医薬品の品質保証検査 に資することを目的とし, 医薬品ごとの THz帯における指 紋スペクトルを分析することで, 医薬品の偽造検査や異種 錠剂・金属・非金属物質の混入検査を行った.

\section{$3 \cdot 1$ 測定医薬品}

現在, 病院等で一般的に処方されており, 消化器系を対 象とする医薬品である下記 5 種（括弧内は薬効分類）につ いて測定を行った。

(a) ブチルスコポラミン臭化物 (鎮痤剤)，（b）ラクトミ ン (整腸剂), (c)レバミピド (消化性潰瘍用剂), (d) ファ モチジン (消化性潰瘍用剤), (e) メトクロプラミド（消化 器機能異常治療剤).

各医薬品については測定の S/N 比を上げるため, 数 100 $\mu \mathrm{m}$ 厚まで薄膜化し測定を行った.

\section{$3 \cdot 2$ 医薬品ごとの THz スペクトル分析}

Fig. 1a に医薬品ごとの THz 吸収スペクトル分析結果を 示す. $0.5 \sim 4.5 \mathrm{THz}$ における吸光特性から, ブチルスコポ ラミン臭化物は $1.36 \mathrm{THz}$ に吸光ピークを, ラクトミンで は $1.13 \mathrm{THz}$ 及び $1.61 \mathrm{THz}$ に吸光ピークを持つことが示さ れており, 医薬品ごとに異なる周波数位置に吸光ピークを 示すことがわかる. 加えて, ファモチジンとメトクロプラ ミドの混合物の吸光ピークを見ると, それぞれの医薬品が 持つ吸光ピークを重ね合わせた吸光特性を示している.こ の吸光ピークは主に医薬品の構成分子における分子間振動 等に起因する $\mathrm{THz}$ 帯特有のものであり, 物質固有の吸収を
示すことから指紋スペクトルと呼ばれる.この指紋スペク トルを測定することで, 可視光による画像検査では判別が 難しい医薬品の偽造防止検査や品質検査が可能となる.

\section{$3 \cdot 3$ 医薬品の品質検査}

前項で取得した医薬品の指紋スペクトルを元に, 非破 壊・非接触での品質検査（医薬品同定・異物混入）を実施 した. Fig. 1bに, 測定した医薬品群 (厚さ $10 \mu \mathrm{m}$ のポリエ チレンフィルムで梱包）の写真と, THz-TDSによって取得 した THz 吸収像を示す. 両医薬品とも白色の錠剤であるた め写真からはこの医薬品の構成物質を同定することはでき ないが, 各周波数帯での $\mathrm{THz}$ 像を測定することで, この医 薬品がファモチジン（右錠剤 : $2.28 \mathrm{THz}$ で強い吸光）とメ トクロプラミド (左錠剤 : $1.36 \mathrm{THz}$ 及び $2.55 \mathrm{THz}$ で強い 吸光）で構成されていることや, 両医薬品が混在している 部分（画像中央: $2.28 \mathrm{THz}$ 及び $1.36 \mathrm{THz}$ の両方で強い吸 光）があること, 両医薬品ともコーティング剤（0.96 THz で強い吸光）が塗布されていることといった医薬品の品質 が分析できる. 加えて, $\mathrm{THz}$ 帯の特徴である材質ごとの吸 光度特性の違いを活かすことで, 金属片（全周波数帯で強 い吸光）やテープ等の非金属 (4 THz 以上の高周波数帯で だんだん吸光が強くなる）といった，医薬品の製造過程で 混入する可能性のある異物の検知も同時に行うことができ る.また, $\mathrm{THz}$ 帯電磁波の特徴である数 $100 \mu \mathrm{m}$ という長 い波長により，污れやゴミといった波長よりも小さなス ケールでの不均一さに影響されず検査が行える，また，梱 包材に対する高い透過率を利用することで, これらの医薬 品が封筒やプラスチックケース等のパッケージ内に梱包さ れた状態にあっても品質検査が行えるという長所も有して いる．以上の結果より，医薬品の非破壊・非接触品質検査 に THz 計測が有用であることが示された。

\section{4 有機膜分析}

近年，製造業界では自動車業界を含む多くの分野でプラ スチック材料の適用が進むことが予想されている.これら プラスチック材料では, 複数の機能を一つの材料に持たせ るため, 多層膜構造にすることがしばしばある.このよう な複合構造では, 久損や異物の混入が生じやすいため, 安 全性確保のためこれらの非接触・非破壊検知技術が注目を 集めている．本項では，有機膜の品質保証検査に資するこ とを目的とし, THz 帯の透過特性を利用して有機膜表面及 び内部に発生した久損・異物混入等の検知を行ったため紹 介する. 分析に際して, 本研究では主に下記の二つの手法 を併用した。

（a）材料の形状が変化する部分で電磁波が回折し，直進 方向の強度が減衰することを利用した分析手法.

（b）材料の構成分子に起因する電磁波共鳴吸収（指紋又 
a
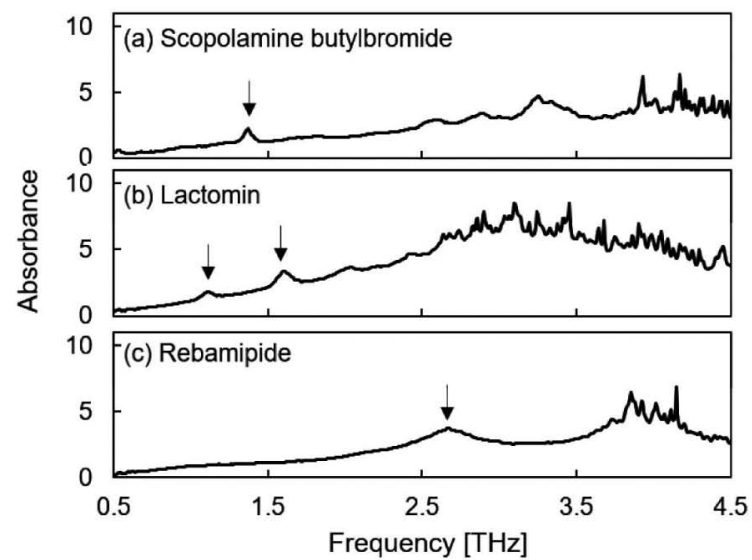

b

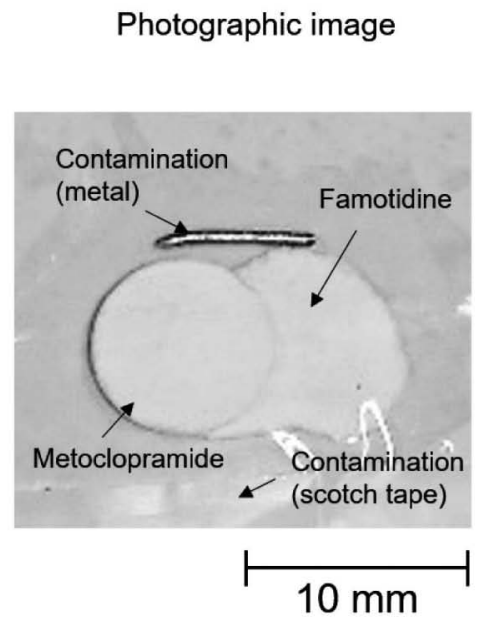

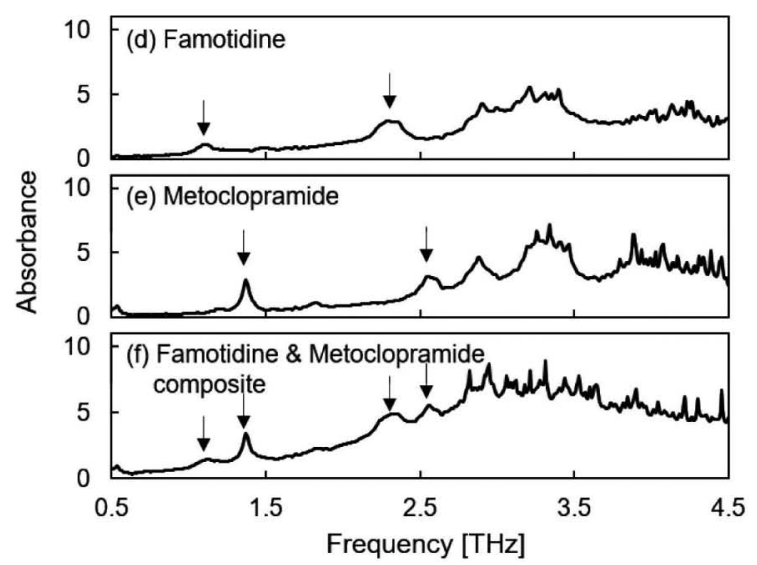

THz images $f=1.36 \mathrm{THz}$

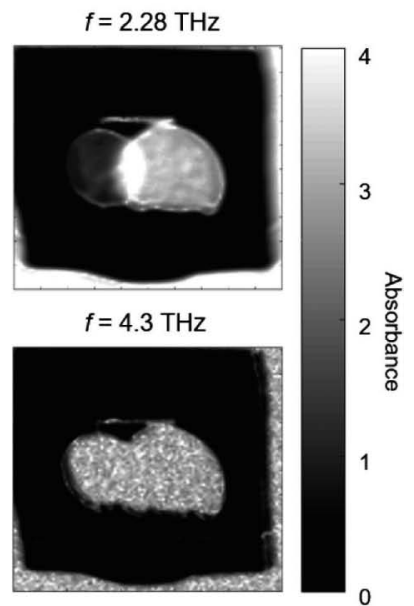

Fig. 1 THz fingerprint spectra and non-invasive inspection of medical drugs

(a) $\mathrm{THz}$ absorption spectra of scopolamine butylbromide, lactomin, rebamipide, famotidine, metoclopramide, and mixture of famotidine and metoclopramide. The arrows indicate the absorption peaks in the fingerprint spectra. (b) Non-invasive inspection of medical drugs. In contrast to the visible light image (left), the THz images (right) enable us to clearly distinguish the contents based on absorption peaks $(0.96 \mathrm{THz}$ for coating agent, $2.28 \mathrm{THz}$ for famotidine, and 1.36, $2.55 \mathrm{THz}$ for metoclopramide). Additionally, the results visualized the contaminations of a metal and a polymer (scotch tape), in which the $\mathrm{THz}$ signals appeared in all frequency range for the metal, and above $4 \mathrm{THz}$ for the scotch tape.

ペクトル）や，電磁波の伝播遅延を利用した分析手法.

有機膜の欠損といった形状に関する分析は（a）を，有機 膜内に混入した不純物の同定や膜厚評価といった材質に関 する分析は（b）を手法として用いた.

\section{$4 \cdot 1$ 測定材料}

有機膜として広く利用されているポリエチレンテレフタ レート（PET）フィルム及びアクリル板を分析対象の材料 として用いた．品質検査の分析手法で広く用いられている 可視光や赤外光と $\mathrm{THz}$ 光を比較すると, 有機膜の $\mathrm{THz}$ 帯 に対する吸光度は低いため, 入射した $\mathrm{THz}$ 光のほとんどが 透過する。そのため, 有機膜が厚膜や多層構造になってい ても内部に発生した欠損や異物混入等の品質を分析するこ とができる. 本研究では有機膜の表面及び内部にクラック
(貫通・非貫通)，気泡（ボイド）を持つ $0.25 \sim 11 \mathrm{~mm}$ 厚 の様々な単層・多層フィルムを準備し，測定を実施した。

\section{$4 \cdot 2$ 有機膜の品質検査}

4・2・1 欠損検査 $\mathrm{THz}$ 帯の透過特性を利用して, 単 一有機膜における久損検査を実施した. 有機膜の $\mathrm{THz}$ 帯に 対する吸光度は低いため, 入射した $\mathrm{THz}$ 光はほとんどが透 過する. しかしながら有機膜内に欠損が存在する場合, 欠 損部の縁で $\mathrm{THz}$ 光が回折し, 結果として検出器に到達する $\mathrm{THz}$ 光の強度が減衰する（見かけ上, 高い吸光度を示す). この特性を用いることで, 貫通・非貫通問わず有機膜に存 在する欠損を非破壊で観測することができる（Fig. 2a）。 な お, この時の空間解像度は, 回折限界により入射光の波長 程度（周波数 $1 \mathrm{THz}$ で波長 $300 \mu \mathrm{m}$ ）に制限される. その 


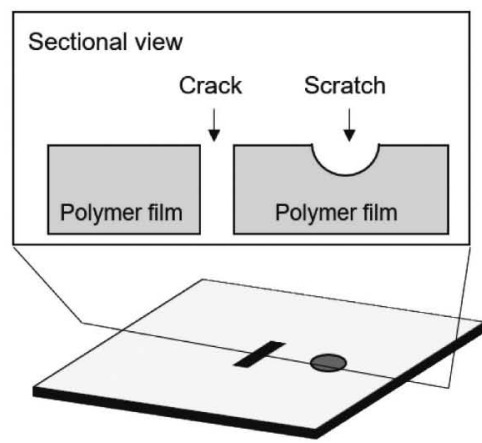

b

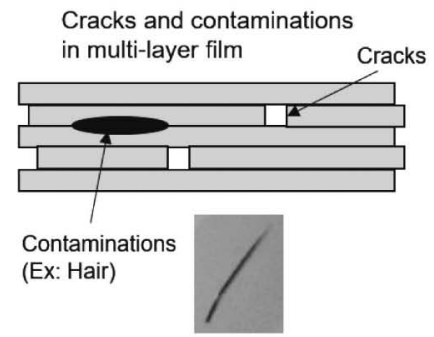

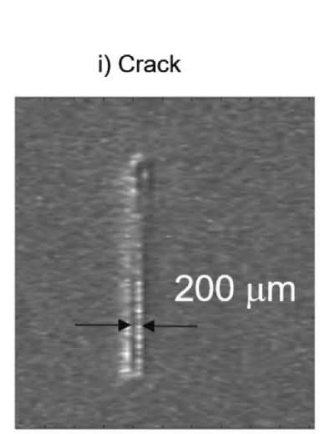

Photographic image

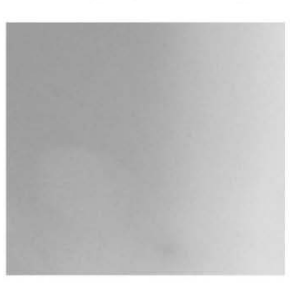

$\mathrm{THz}$ images

ii) Scratch (3 mm)

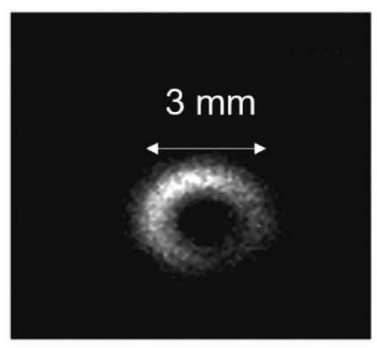

iii) Scratch (1 mm)

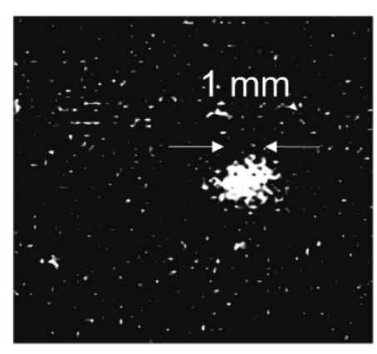

THz images

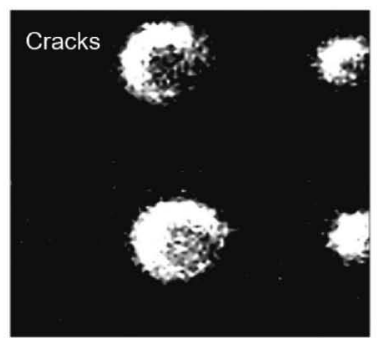

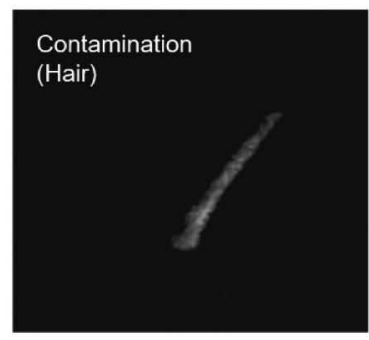

Fig. 2 Non-destructive quality inspection of polymer films with $\mathrm{THz}$ imaging

(a) THz imaging of cracks and scratches of the polymer film. (b) Quality inspection of cracks and contaminations inside the multi-layer polymer film. By utilizing the relatively high $\mathrm{THz}$ transmission through the polymer and the wave diffraction at the edges of objects, we successfully identified, in a non-destructive manner, cracks and metal/ non-metal contaminations in the polymer films. The spatial imaging resolution primarily depends on the wavelength of $\mathrm{THz}$ waves.

ため, 赤外領域に向かい周波数を高くしていくと解像度は 向上するが, 反面入射光の透過率が減衰し $\mathrm{S} / \mathrm{N}$ 比が劣化し てしまうため, 厚膜材料の分析が難しくなる。一方, マイ クロ波領域に向かい周波数を低くしていくと透過率が上昇 し, より厚い材料まで分析可能となるが, 解像度は数 $\mathrm{cm}$ 程度まで劣化してしまい, 微細な破損の分析ができなく なってしまう。これらの特徵から, 測定対象の吸光特性や 欠損の大きさに合わせて適切に周波数を選択することが, 正しい分析を行うためには大切である.

次に有機膜の積層化工程で多層有機膜の内部に発生した 久損や異物混入の検査を実施した. Fig. $2 \mathrm{~b}$ に測定結果を示 す. $\mathrm{THz}$ 帯の透過特性を利用することで, 可視光や赤外光 では判別の難しい多層有機膜内部の欠損や非金属物質（髮 の毛等）の混入といった品質劣化が分析できている．これ らの結果は THz 帯特有の分析結果であり, THz イメージ ングが多層有機膜の品質検查に有力な手法の一つとなり得 ることがわかる.

$\mathbf{4 \cdot 2 \cdot 2}$ 混入物分析 次に $\mathrm{THz}$ 帯の指紋スペクトルを 利用した多層有機膜内部の気泡（ボイド）検查及び混入物 分析を実施した．欠損・破損のような大きな形状変化を伴 う測定対象と異なり, ボイドの縁では入射光が微弱にしか 回折しないため, 前項のような回折を利用した分析は適用 できない，しかしながら， 3 項にて前述の通り, $\mathrm{THz}$ 領域
の周波数帯には固体・液体・気体問わず多くの物質の指紋 スペクトルが存在する，そのため，ボイド内部に含まれる 物質に起因する $\mathrm{THz}$ スペクトルを分析することで, 有機膜 内のボイド検査や，ボイドに含まれるガス（湿気や有毒ガ ス等）の分析, 製造過程で混入する可能性のある溶液（例 えば，コンデンサ製造時における電解液等）の漏洩検查が 可能となることを示唆している.

Fig. 3 に乾燥気泡, 高湿度気泡, エ夕ノールを含んだ有 機膜のスペクトル分析結果及び, 各周波数帯での THz 吸収 画像を示す，得られた $\mathrm{THz}$ 画像を比較すると, ボイドの縁 では回折が微弱なため, Fig. 2のような測定対象の縁での 強い回折信号は観測されない（実験の都合上，エタノール のみ毛細管現象によってボイドの縁で液化しているため, 縁で強い回折信号が見えている）が，代わりに，ボイド内 部の分子ダイナミクスに起因する吸光信号を分析すること で，ボイドの存在を観測することができる，加えて，ボイ ド部分での指紋スペクトルを比較することで, $1.03 \mathrm{THz}$, $1.66 \mathrm{THz}$ 及び $2.44 \mathrm{THz}$ で強い吸光ピークを示す部分は水 滴 (強度は湿度に依存), $0.85 \mathrm{THz}, 1.03 \mathrm{THz}$ 及び $1.66 \mathrm{THz}$ で強い吸光ピークを示す部分はエタノールであると特定で き，ボイド内部の物質分析が可能となる (Fig. 3c 下図にお いてエタノールの縁では全周波数において強い吸光特性を 示しているが, これは回折による透過率隇少であるので, 
a

(i) (ii)

\begin{tabular}{|l|}
\hline Protection film \\
\hline Polymer \\
\hline
\end{tabular}

(iii)

\begin{tabular}{|l|}
\hline Protection film \\
\hline Polymer \\
\hline
\end{tabular}

Photographic image of (i)

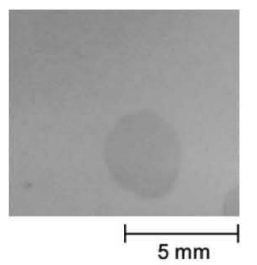

C

$f=0.85 \mathrm{THz}$
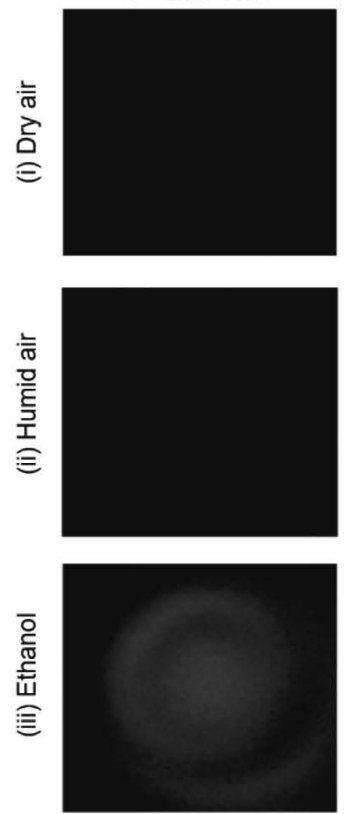

$f=1.03 \mathrm{THz}$
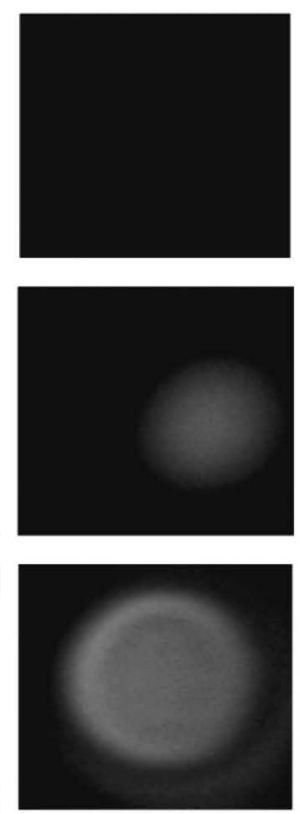

b

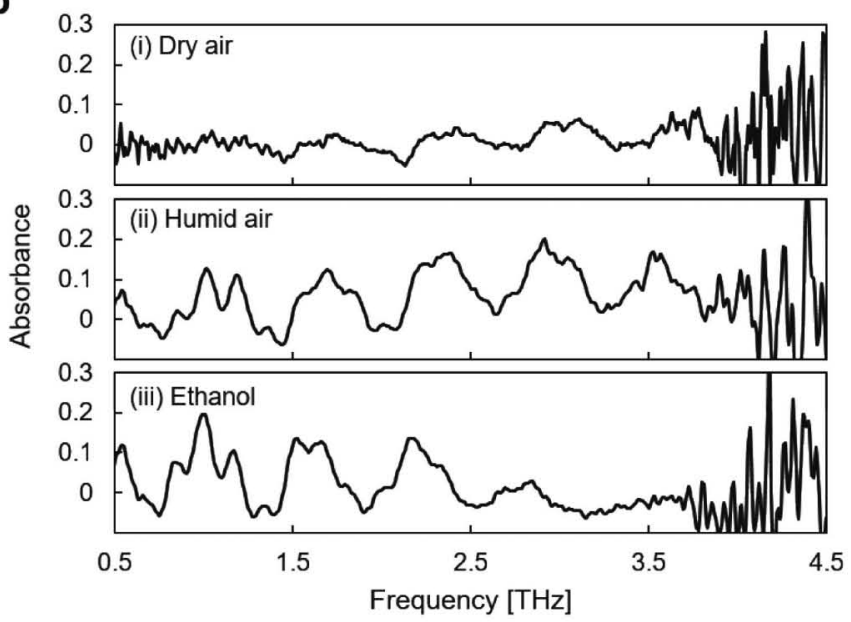

THz images

$f=1.41 \mathrm{THz}$

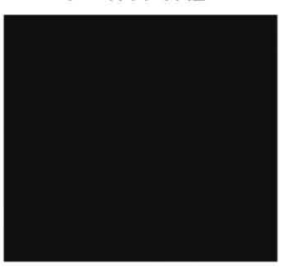

$f=1.66 \mathrm{THz}$
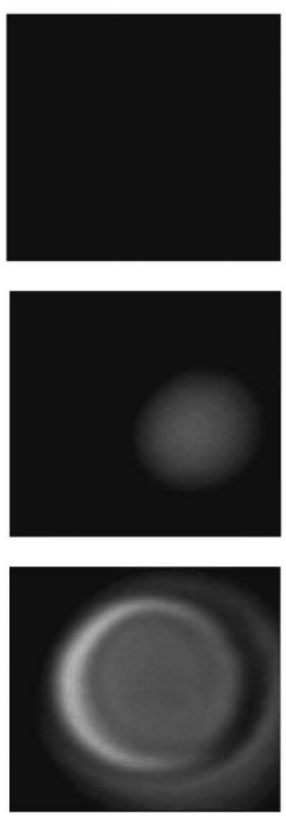

$f=2.44 \mathrm{THz}$
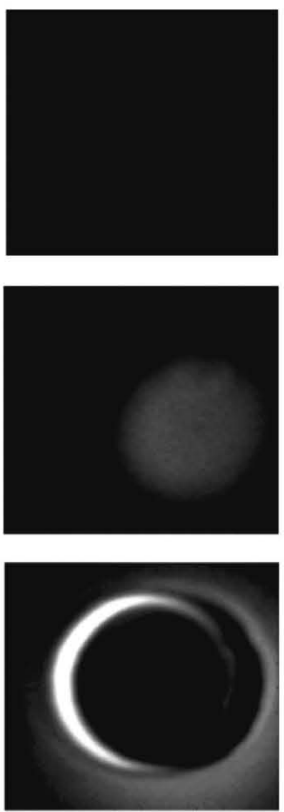

Fig. 3 Analysis of the contents inside the voids of the polymer film

(a) Schematic view of the polymer films used and photographic image of (i) (b) $\mathrm{THz}$ absorption spectra of three types of polymer samples. The difference in the $\mathrm{THz}$ absorbance allowed us to identify contents inside the voids. (c) Non-contact inspection of the contents inside the voids of the polymer film. Here dry air, humid air, and ethanol were clearly distinguished from the obtained $\mathrm{THz}$ spectroscopic images. The apparently high $\mathrm{THz}$ absorption at the edge of ethanol originates from the wave diffraction (not from the absorption spectrum of ethanol).

エタノール分子由来の吸光特性ではないことに留意する必 要がある)。

$\mathbf{4} \cdot \mathbf{2} \cdot \mathbf{3}$ 膜厚評価最後に, THz-TDSにて得られた $\mathrm{THz}$ パルス波の時間波形を元に有機膜の膜厚評価を実施 した，媒質中を伝搬する電磁波の速度は，媒質の誘電率と 透磁率によって変化するという特性がある. そのため, 有 機膜を透過した $\mathrm{THz}$ パルス波が検出器に到達する時間は, 有機膜の厚さ（ $\mathrm{THz}$ 波が有機膜を伝搬する距離）に依存し て遅くなる。この特性は, 遅延時間を分析することで媒質 の屈折率や厚さを計測できることを示唆している.
Fig. 4 に有機膜の膜厚を変えた際の $\mathrm{THz}$ パルス光の時間 波形を, Table 1 に有機膜の膜厚及び気泡の有無に対する 遅延時間を示す。実験結果から, 膜厚に比例して $\mathrm{THz}$ パル ス光の検出器までの到達時間が遅くなっていることがわか る.また, 同一膜厚の場合, 有機膜内に欠損部分（主に空 気で構成されている）があるほど, $\mathrm{THz}$ 光が有機膜を伝搬 する距離が短くなるため, 遅延時間は減少する。これらの 結果は, 有機膜内部では誘電率の分だけ $\mathrm{THz}$ パルス光の伝 搬速度が減少し $\mathrm{THz}$ パルス光が膜内部を通過する時間が 長くなるという現象に由来する.この特性を活かし, 有機 


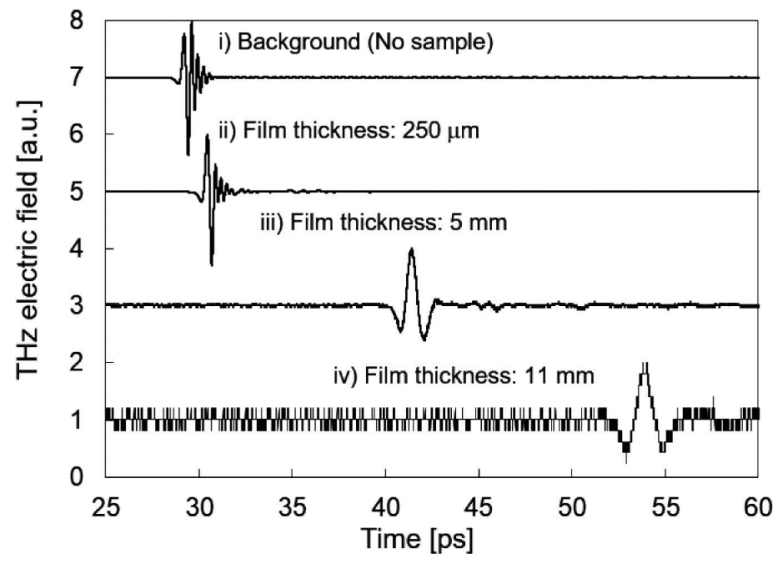

Fig. 4 Time-domain THz signals of the polymer film upon $\mathrm{THz}$ pulse irradiation for different thicknesses Because the speed of the electromagnetic wave depends on the refractive index of materials, the signal of the $\mathrm{THz}$ wave propagated through the polymer film was delayed in time. On this basis, we evaluated the film thickness by measuring the delay time.

膜を透過した $\mathrm{THz}$ パルス光の遅延時間を分析することで, 有機膜の膜厚及び気泡の大きさを評価することが可能とな る.

なお, 本有機膜は高周波帯ほど $\mathrm{THz}$ 光をよく吸収する特 性を有しているため, 膜厚が厚くなるほど高周波成分が透 過しにくく，低周波成分だけが透過するようになる，その 結果として, 膜厚が厚くなるにつれて, 低周波成分のみが 残った（時間周期が長い） $\mathrm{THz}$ パルス光が観測される. こ のように，通過した $\mathrm{THz}$ パルス光の波形を観測すること で, 材料が持つ吸収特性を評価することも可能である。

$$
5 \text { 結 言 }
$$

本研究では, 材料分析の新手法として期待される $\mathrm{THz}$ 計 測を用いて医薬品や有機膜等の品質検査を実施した。 $\mathrm{THz}$ 帯電磁波特有の有機物に対する適度に高い透過率や指紋ス ペクトルを利用することで, 超音波や可視光による画像解 析等, 他の分析手法では難しい, 医薬品の分子同定や多層 有機膜内部におけるサブミリスケールの欠損検査等の品質 検査を達成した。

近年, 医薬品や工業用材料に対する安全性・信頼性の需 要は年々増加してきており, これら製品の非破壊・非接触 分析手法の開発・導入は国際的に大きな注目を集めてい る. 本研究成果である $\mathrm{THz}$ 空間・時間・周波数分解計測を 用いた医薬品・有機膜等の分析は, 既存の分析手法では難 しい構成分子の同定や多層有機膜内部の欠損検査, 髪の毛 等の非金属物質の混入検査を可能にする強力な分析手法で あり, 安心・安全な製品の供給に貢献することが期待され る.
Table 1 Time delay of $\mathrm{THz}$ signals through polymer films with different thicknesses

\begin{tabular}{ccc}
\hline Film thickness $[\mathrm{mm}]$ & Crack $[\mathrm{mm}]$ & Delay time $[\mathrm{ps}]$ \\
\hline Background (No sample) & None & 0 (Reference) \\
0.25 & None & 1 \\
5 & None & 12.19 \\
5 & 0.25 & 11.99 \\
5 & 1 & 11.12 \\
11 & None & 24.7 \\
\hline
\end{tabular}

The thicker polymer film and/or the existence of cracks (air) in the film result in the delay of the $\mathrm{THz}$ pulse propagation. These features enable to estimate the film thickness and the crack size.

著者らは今後も引き続き, $\mathrm{THz}$ 計測による薬品検査や有 機材料の組成判定といった分析手法の開発を行い, $\mathrm{THz}$ イ メージングの実用化を推進していく予定である.いくつか の開発項目の中で, 測定時間の高速化や測定装置の小型 化，様々な表面形状を持つ試料への適用は必須の課題であ る. 著者らは最近, 測定環境や対象を限定しないフレキシ ブルな $\mathrm{THz}$ カメラを開発した ${ }^{17)}$. THz 分光により得られた スペクトル情報を元に連続波光源とフレキシブル $\mathrm{THz}$ カ メラを用いることにより, 全方位からの高速 $\mathrm{THz}$ 画像検査 が可能となっており, THz 計測の応用範囲を広げることが 期待できる.

\section{謝辞}

本研究は, JST 未来社会創造事業, JST 地域産学バリュー プログラム, JST 産学共創基礎基盤研究プログラム, JST セ ンターオブイノベーションプログラム, JSPS 科研費 (JP17K19026, JP17H02730, JP16H00798, JP16H00906, JP16J09937), 村田財団研究助成,「東工大の星」による支 援の元に遂行された.

\section{文献}

1) T. Sakamoto: Abstracts of The Annual Meeting of the Spectroscopical Society of Japan, 25 (2017).

2) P. Janos : WHO Drug Information, 22, 177 (2008).

3) R. Shillarege, I. S. Bhandari, J. K. Chaar, M. J. Halliday, B. K. Ray, M. Y. Wong : IEEE T. Software Eng., 18, 943 (1992).

4) E. Grosso, A. Lagorio, M. Tistarelli : Mach. Vision. Appl., 22, 269 (2011).

5) S. Cubero, N. Aleixos, E. Molto, J. Gomez-Sanchis, J. Blasco : Food. Bioproc. Tech., 4, 487 (2011).

6) Y. W. Wu, S. Q. Sun, Q. Zhou, H. W. Leung: J. Pharmaceut. Biomed., 46, 498 (2008).

7) T. Ozaawa, M. Yokoyama, T. Hosono, T. Nagato, K. Tahara, H. Takeuchi : Int. J. Pharm., 458, 9 (2013).

8) M. Ito, T. Suzuki, N. Wakiyama, H. Teramoto, E. Yonemochi, K. Terada : Chem. Pharm. Bull., 59, 868 (2011).

9) R. P. Haff, N. Toyofuku : Sens. \& Instrumen. Food Qual., 2, 262 (2008).

10) G. Ayalew, N. M. Holden, P. M. Grace, S. M. Ward : 
Comput. Electron. Agr., 42, 1 (2004).

11) R. Kohler, A. Tredicucci, F. Beltram, H. E. Beere, E. H. Linfield, A. G. Davies, D. A. Ritchie, R. C. Iotti, F. Rossi : Nature, 417, 156 (2002).

12) X. He, N. Fujimura, J. M. Lloyd, K. J. Erickson, A. A. Talin, Q. Zhang, W. Gao, Q. Jiang, Y. Kawano, R. H. Hauge, F. Leonard, J. Kono : Nano Lett., 14, 3953 (2014).

13) T. Iguchi, T. Sugaya, Y. Kawano : Appl. Phys. Lett., 110, 151105 (2017).
14) Y. K. Lee, S. W. Choi, S. T. Han, D. H. Woo, H. S. Chun : J. Food Protect., 75, 179 (2012).

15) K. Kawase, Y. Ogawa, Y. Watanabe, H. Inoue : Opt. Exp., 11, 2549 (2003).

16) F. Ospald, W. Zouaghi, R. Beigang, C. Matheis, J. Jonuscheit, B. Recur, J. P. Guillet, P. Mounaix, W. Vleugels, P. V. Bosom, L. V. Gonzalez, I. Lopez, R. M. Edo, Y. Sternberg, M. Vandewal : Opt. Eng., 53, 031208 (2013).

17) D. Suzuki, S. Oda, Y. Kawano: Nat. Photon., 10, 809 (2016).

\title{
Terahertz Imaging and Spectroscopy as a Tool for Non-destructive and Non-contact Quality Inspections of Medical Drugs and Polymer Films
}

\author{
Daichi SUZUKI ${ }^{1,2}$ and Yukio KAWANO ${ }^{* 1}$ \\ *E-mail : kawano@ee.e.titech.ac.jp \\ ${ }^{1}$ Laboratory for Future Interdisciplinary Research of Science and Technology, Tokyo Institute of Technology, \\ 2-12-1, Ookayama, Meguro-ku, Tokyo 152-8552 \\ ${ }^{2}$ Research Fellow of Japan Society for the Promotion of Science, 5-3-1, Kojimachi, Chiyoda-ku, Tokyo 102-0083
}

(Received July 26, 2017; Accepted October 2, 2017)

The development of non-destructive quality inspection methods has been increasingly attracting much attention to ensure the reliability and safety of products, especially in the fields of medicine and materials engineering. In this work, we used terahertz $(\mathrm{THz})$ imaging and spectroscopy as a novel analysis method for in-process quality inspections of medical drugs and polymers. By utilizing advantageous features of $\mathrm{THz}$ waves, such as relatively high transmission through objects and $\mathrm{THz}$ fingerprint spectra of polymers, we demonstrated nondestructive and non-contact quality inspections, such as the identification of mixtures of medical drugs, the detection of cracks and organic/inorganic contaminations inside multi-layer polymer films, and the evaluation of polymer film thickness. These results indicate that the inspection method based on $\mathrm{THz}$ technology can be powerfully used as a quality assurance system.

Keywords: terahertz imaging; terahertz spectroscopy; non-destructive inspection; in-process inspection. 